\title{
Relationship Between Family Support and Activeness of Prolanis Participants With Diabetes Mellitus
}

\author{
$1^{\text {st }}$ Ananda HS \\ STIKES 'Aisiyah Bandung \\ Bandung, Indonesia \\ ndgjem@yahoo.com
}

\author{
$2^{\text {nd }}$ Nandang Jamiat \\ STIKES 'Aisiyah Bandung \\ Bandung, Indonesia
}

\author{
$3^{\text {rd }}$ Hendra Gunawan \\ STIKES 'Aisiyah Bandung \\ Bandung, Indonesia
}

\begin{abstract}
The cause of the increased prevalence of diabetes mellitus is a change in lifestyle and socioeconomy. Family support is an important thing in the management of diabetes mellitus. One of the diabetes mellitus prevention program is a program of chronic disease managament (prolanis). The purpose of this study was to know the relationship between family support and activeness of prolanis participants with diabetes mellitus. This study used a correlative quantitative research design conducted in 2019 in Bandung. The samples in this study were 43 respondents. The sampling technique used in this study was total sampling. The data collected involved family support and activeness of participants by using a questionnaire instrument of family support and activeness of participants. Statistical test used Spearman Rank Correlation. The analysis result showed that there is a relationship between family support and activeness of participant level $(P \leq 0.05)$. It is suggested for government to educate about diabetes mellitus and how to care for it to the family of patients with diabetes melittus.
\end{abstract}

Keywords-Diabetes Mellitus, Prolanis, Family Support

\section{INTRODUCTION}

Diabetes Mellitus (DM) is a generative and chronic disease. Indonesia is in the fourth position in the world which has the most diabetes mellitus sufferers. Data in 2018 increased from $6.9 \%$ to $8.5 \%$ [1], and the incidence of DM in Bandung as many as 4,761 cases occurred in 2018 [2].

The government has developed a DM control program called the chronic disease management program (Prolanis). Prolanis is a health care system and an effective approach conducted integrated which involve the participants, health facilities and BPJS (Badan Penyelenggara Jaminan Sosial/Indonesia National Health Insurance) in the frame of maintaining the BPJS participants' health who have chronic diseases to reach optimal life quality with effective and efficient cost. Prolanis was aimed to reduce the risk of complication and achieve a good quality of life with effective and rational cost utilization [3]. The number of DM participants in Talagobodas Public Health Centre as many as 104 people, but none of them check their health regularly. One of the factors that can affect the DM prolanis participants in examining themselves is family support. Some of the patients with DM try to follow the suggested treatment but they do not always succeed because the social support is still low. Family support is an important element in the management of Diabetes Mellitus because family members help the patients with DM to maintain obedience. It is needed a study about the relationship between family support and activeness of DM prolanis participants in Talaga Bodas Public Health Centre Bandung.

\section{METHOD}

This study used a correlative quantitative method with cross-sectional approach. The population in this study was 43 DM prolanis participants using total sampling. The independent variable was family support while the dependent variable was the active DM prolanis participants.

To test the validity of the questionnaire, product moment correlation techniques were conducted [4]. Reliability test used the Cronbach alpha formula showing that $r$ Alpha was $>r$ table. The reliability test results of the questionnaire were reliable with Cronbach's alpha value $=0.998$, with $\mathrm{r}$ table $=$ 0.444. Hypothesis test used Spearman Rank Correlation [5]. The study was conducted from April to June 2019.

\section{RESULT}

TABLE 1. DISTRIBUTION OF PROLANIS PARTICIPANT BASED ON GENDER

\begin{tabular}{|c|c|c|c|}
\hline No & Gender & Frequency & Percentage \\
\hline 1 & Male & 18 & $41.9 \%$ \\
\hline 2 & Female & 25 & $58.1 \%$ \\
\hline \multicolumn{2}{r|}{ Total } & 43 & $100 \%$ \\
\hline
\end{tabular}

Based on Table 1, it was known that the frequency of female respondents were more than male as many as 25 respondents $(58.1 \%)$. This was caused by the differences of sick behavior pattern influenced by gender. The female tends to more often check her health than male. In addition, the time available of female is more than male in seeking treatment in Public Health Centre. 
TABLE 2. DISTRIBUTION OF PROLANIS PARTICIPANT BASED ON AGE

\begin{tabular}{|c|c|c|c|}
\hline No & Age & Frequency & Percentage \\
\hline 1 & $45-55$ years & 2 & $4.7 \%$ \\
\hline 2 & $56-65$ years & 15 & $34.9 \%$ \\
\hline 3 & $66-75$ years & 12 & $27.8 \%$ \\
\hline 4 & $76-85$ years & 14 & $32.6 \%$ \\
\hline & Total & 43 & $100 \%$ \\
\hline
\end{tabular}

According to table 2, the most respondents based on age was the group aged 56-65 years old (34.9\%) because this group is an age group susceptible to DM. Increased age is an important risk factor for Diabetes Mellitus. This disease is more prevalent occurred in people aged over 40 years than in younger people.

TABLE 3. DISTRIBUTION OF PROLANIS PARTICIPANTS BASED ON EDUCATIONAL LEVEL

\begin{tabular}{llcl}
\hline No & Education & Frequency & Percentage \\
\hline 1 & Elementary school & 2 & $4.7 \%$ \\
\hline 2 & Middle school & 7 & $16.3 \%$ \\
\hline 3 & High school & 14 & $32.6 \%$ \\
\hline 4 & Diploma & 8 & $18.5 \%$ \\
\hline 5 & Bachelor & 11 & $25.6 \%$ \\
\hline 6 & Doctor & 1 & $2.3 \%$ \\
\hline Total & & 43 & $100 \%$ \\
\hline
\end{tabular}

Based on Table 3, the most prolanis respondents based on the educational background were the respondents graduated from high school as many as 14 respondents (32.6\%). The higher the education, the higher the desire to utilize knowledge and skills, and will choose the tendency to fulfill desires with higher demands and expectations.

TABLE 4. DISTRIBUTION OF PROLANIS PARTICIPANTS BASED ON TYPES OF JOB

\begin{tabular}{|l|l|c|c|}
\hline No & \multicolumn{1}{|c|}{ Work } & Frequency & Percentage \\
\hline 1 & Labor & 1 & $2.3 \%$ \\
\hline 2 & Housewife & 16 & $37.2 \%$ \\
\hline 3 & Employee & 2 & $4.7 \%$ \\
\hline 4 & Retired & 21 & $48.8 \%$ \\
\hline 5 & Government employees & 1 & $2.3 \%$ \\
\hline 6 & Entrepreneurship & 2 & $4.7 \%$ \\
\hline \multicolumn{2}{|l|}{ Total } & 43 & $100 \%$ \\
\hline
\end{tabular}

Based on table 4 , the most respondents based on the types of job in this study were retired as many as 21 respondents $(48.8 \%)$. Based on the results of the study, retired and house wife affect the obedience DM prolanis respondents to participate in DM Prolanis activities. Respondents who are retired and housewives have more free time so that they think more about positive activities that can be done. Since they suffer from diabetes mellitus, they should join the DM Prolanis program.

TABLE 5. BIVARIATE ANALYSIS RESULT OF RELATIONSHIPS BETWEEN FAMILY SUPPORT AND ACTIVENESS OF DM PROLANIS PARTICIPANTS

\begin{tabular}{|l|c|c|c|c|c|}
\hline Family support & \multicolumn{3}{|c|}{ Participation Activeness } & Total & \multirow{2}{*}{$\begin{array}{c}\text { v } \\
\text { value }\end{array}$} \\
\cline { 2 - 5 } & $\begin{array}{l}\text { Less } \\
\text { Active }\end{array}$ & $\begin{array}{c}\text { Quite } \\
\text { active }\end{array}$ & $\begin{array}{c}\text { Very } \\
\text { active }\end{array}$ & & \\
\hline Do not support & 0 & 0 & 0 & 0 & 0.002 \\
\hline Support enough & 0 & 0 & 0 & 0 & \\
\hline Verry support & 0 & 24 & 19 & 43 & \\
\hline Total & 0 & 24 & 19 & 43 & \\
\hline
\end{tabular}

Table 5 shows that the test results using spearman Rank Correlation were $P$ value $(0.002)$ which is lower than 0.005 or $\mathrm{P}<0.05$ then the hypothetical result was accepted meaning that there is a relationship between family support and activeness of DM prolanis participants in Talaga Bodas Public Health Centre Bandung . According to the table, there were 24 respondents $(55.8 \%)$ who received) who accepted family support.

\section{DISCUSSION}

\section{A. Family support}

In this study, the whole respondents received family support who were in very support category consisting of 24 respondents $(55.8 \%)$ in the active enough category. In addition, there were 19 respondents $(44.6 \%)$ in the very active category. From the result, it can be seen that the respondents' family has given support to the DM prolanis participants to be active in Talaga Bodas Public Health Centre. Their family also care about the participants' need, they want to listen to the participants' complain and also give an assistance for the participants in doing their daily activity.

The result that has been done by Putri Fatimah (2018) described that family support very influences the obedience of DM management. If the participants' family do not support, it will influence the obedience of DM management [6]. The family support can be done by :

(1) Giving informative support including suggestions, advises, instructions and information.

(2) Giving assessment support including feedback guidance, problem solving as a source and identity validity of family members such as support, award and attention.

(3) Giving instrumental support including concrete and practical assistance such as the patients' health in case of eating and drinking needs, taking a rest, tiredness. 
(4) Giving emotional support including a support which is manifested in the form of affection, trust, attention, listen and being heard

One of method family support is diabetes selfmanagement education (DSME), which provided to most newly diagnosed diabetic patients. This method found early initiation of DSME was associated with better glycemic control during the first year among study subjects, but not afterward. The insulin regimen and family factors were associated with good glycemic control [7].

\section{B. The activeness of Prolanis Participants}

Seen from the activeness, it can be known that the activeness of the participants in participating the Prolanis program was quite enough as many as 24 respondents $(55.8 \%)$, while the respondents in the very active category were 19 respondents $(44.2 \%)$.

The level of the participants activeness in participating in the Prolanis at the Talaga Bodas Public Health Center was in the quite active category. The activeness of the elderly in the utilization of health services is influenced by several factors, namely attitude, availability of facilities and infrastructure, geographical location, attitude of officers, and family support. The location of Talaga Bodas Public Health Center is located next to Lengkong subdistrict office and its location is not too far from residential areas so the societies can easily reach the public health centre. The existence of facilities and infrastructure as well as easy access become an attraction for the participants to attend Prolanis activities. This research related with Arifin et. all (2019) that internal diabetes distress consists of disease burden, fatigue due to type 2 diabetes mellitus, fatigue not due to type 2 diabetes mellitus, emotional burden and lack of knowledge. Internal coping strategies comprised spirituality, positive attitude, acceptance and getting more information about type 2 diabetes mellitus. External diabetes distress was evoked by distress concerning healthcare services, diet, routine medication, monthly blood sugar checks, interpersonal distress (family) and financial concern. External coping strategies included healthcare support, traditional medicine, vigilance, self-management, social and family support and obtaining information about health insurance[8].

Activities member of prolanis influenced by information from family and the other experiences. Ligita et all (2019) people with diabetes initially sought out information; often from family and friends who also had experiences with diabetes. Next the person proceeded to process this received information to make sense of it [9].

c. Relationship of Family Support with the Activeness of DM Prolanis Participants

From the results of bivariate analysis with Spearman Rank Correlation, the P value of 0.002 was obtained with a significance of $\mathrm{p}<0.05$ meaning that there was a relationship between family support and activeness of DM patients. The family supports include always reminding the participants about the prolanis activity schedule and advising the participants to be active in the prolanis at schedule of prolanis activities at Talaga Bodas Public Health Center.

The results of this study is in accordance with the research conducted by Desy Nurbalqis (2018) stating that there is a relationship between family support and the obedience in doing sport [10]. It means that the better the family support, the more obedient the respondents to do sport. This is in line with the study done by Putri Fatimah (2018) explaining that the family support really influences the obedience of DM management. If the family support is not done, it will influence the obedience of DM management [6].

By being given a support from the family, the participants will feel calm and happy in themselves. Moreover, the participants will feel spirit in participating the activities at Talaga Bodas Public Health Centre. The family has an important role in giving support to the participants before the others give the support to them. The family support make satisfaction member of prolanis with diabetes. Although satisfaction with and amount of social support an individual received were significantly and positively related to one another, being satisfied with diabetes-related social support was more important than amount of social support received in terms of Quality of Life (QOL). Better social support may positively influence disease management burden and quality of life [11].

The relationship pattern of family support and the activeness showed that the bigger the family support is, the bigger the activeness of the participants in participating elderly Posyandu (Pos Pelayanan Terpadu/Integrated Health Post). In turn, the lower the family support is, the lower the activeness in participating elderly Integrated Health Post.

\section{CONCLUSIONS}

Based on the results of research on the Relationship of family support and the activeness of Diabetes Mellitus prolanis participants at Talaga Bodas Public Health Centre in Bandung using the correlative method involving 43 respondents, it can be concluded that this study used the Spearman Rank Correlation results obtaining $\mathrm{P}$ value of 0.002 means that the $\mathrm{P}$ value was smaller than 0.005 . From that result, it can be concluded that there is a relationship of family support and the activeness of DM Prolanis participants. The general description of family support is very supportive, consisting of 24 respondents $(55.8 \%)$ in the quite active category and 19 respondents $(44.2 \%)$ in the very active category.

\section{ACKNOWLEDGMENT}

We would like to thank the Chairman of the Stikes Aisyiyah Bandung for providing this study facility. We would like to express our highest thanks and appreciation to the Talagabodas Public Health Center and the staff who have agreed to provide the study's permission. Acknowledgments were also given to the DM prolanis participants who contributed a lot to the success of this study. 


\section{REFERENCES}

[1] D. K. R. Indonesia, "Laporan Hasil Riset Kesehatan Dasar (Riskesdas) Nasional 2018," Jakarta Kementeri. Kesehat. RI, 2018.

[2] Dinas Kesehatan Kota Bandung, "Laporan Kejadian 2019 Penyakit Tidak Menular," Bandung, 2019.

[3] B. Kesehatan, "Panduan praktis prolanis (program pengelolaan penyakit kronis)," Jakarta BPJS Keseharan, 2014.

[4] Sugiyono, Metode penelitian pendidikan:(pendekatan kuantitatif, kualitatif dan R \& D). Bandung: Alfabeta, 2015.

[5] M. S. Dahlan, "Statistik Untuk Kedokteran dan Kesehatan, Penerbit Salemba Medika.” Jakarta, 2012.

[6] P. Fatimah, "Hubungan antara Dukungan Keluarga dengan Kepatuhan Penatalaksanaan Diabetes Mellitus pada Pasien Diabetes Mellitus di RSUD Dr. Pirngadi Medan,” 2018.

[7] S. Patjamontri et al., "The Effect Of Early Diabetes SelfManagement Education On Glycemic Control In Children With Type 1 Diabetes," Southeast Asian J. Trop. Med. Public Health, vol. 49, no. 2, pp. 304-313, 2018.

[8] B. Arifin et al., "Diabetes is a gift from god'a qualitative study coping with diabetes distress by Indonesian outpatients," Qual. Life Res., pp. 1-17, 2019.

[9] T. Ligita, K. Wicking, K. Francis, N. Harvey, and I. Nurjannah, "How people living with diabetes in Indonesia learn about their disease: A grounded theory study," PLoS One, vol. 14, no. 2, p. e0212019, 2019.

[10] D. Nurbalqis, "Hubungan Dukungan Keluarga terhadap Kepatuhan Berolahraga pada Penderita Diabetes Mellitus di Kecamatan Medan Labuhan Tahun 2018,” 2018.

[11] P. G. Bowen, O. J. Clay, L. T. Lee, J. Vice, F. Ovalle, and M. Crowe, "Associations of social support and self-efficacy with quality of life in older adults with diabetes," J. Gerontol. Nurs., vol. 41, no. 12, pp. 21-29, 2015. 